\title{
Toxicological effects of the concurrent administration of cadmium and arsenic through the food chain on the liver and kidney of rats
}

\author{
Theresa Ezedom ${ }^{1,2^{*}}$, Samuel Asagba ${ }^{2}$ and Nyerhovwo J. Tonukari ${ }^{2}$
}

\begin{abstract}
Background: Our environment is filled with a mixture of toxic elements.

Objectives: This study seeks to assess the effects of exposure to cadmium and arsenic through the food chain on the liver and kidney of rats.

Methodology: Adult male albino rats were exposed to experimental feed of which the protein composition was made of fish exposed to cadmium and arsenic for 1 month at a concentration of $0.4 \mathrm{mg}$ cadmium or/and arsenic/ $100 \mathrm{ml}$ water for 1 and 3 months. Samples of feed and tissue were assayed for cadmium and arsenic load. Tissue homogenates were used for biochemical analysis and the estimation of the expression levels of mRNA of Bax and $\mathrm{Bcl} 2$ genes in the liver and kidney of rats were carried out. Samples of tissues were also used for histological analysis.

Results: Results show a greater accumulation of metals in the liver than kidney of rats after the 1-month exposure of which the trend changed after the 3-month exposure. Alterations in enzymatic activities and levels of MDA and GSH were also recorded. Significant $(P<0.05)$ alterations in the level of mRNA expression of the Bax and $B c l 2$ genes were observed in all groups compared to the control for both duration of treatment. Treatment-related lesions were also observed for the various groups from the histopathological analysis.
\end{abstract}

Conclusion: The cadmium-contaminated diet was found to be more toxic to the kidney while the arsenic-contaminated diet was found to be toxic to the liver. In addition, the present study has shown that the toxicity of a mixture of As $+\mathrm{Cd}$ cannot be predicted from the toxic mechanisms of the single components.

Keywords: Bcl2, Bax, Liver, Kidney, Cadmium, Arsenic

\section{Background}

Cadmium and arsenic are well-known toxic metals capable of having adverse effects on the liver and kidney most especially on prolonged occupational or environmental exposure (Madden \& Fowler, 2000). Accumulation of these metals takes place primarily in the liver and kidneys, and their toxic effects depend on the duration and dose of

\footnotetext{
* Correspondence: tessyben@gmail.com

${ }^{1}$ Department of Medical Biochemistry, Delta State University, Abraka, Nigeria ${ }^{2}$ Department of Biochemistry, Delta State University, Abraka, Nigeria
}

exposure (Eichler et al., 2006; Kim, Cho, \& Kim, 2003). These two metals are usually released into our environment due to their wide industrial usage (Yuan et al., 2014). Cadmium is highly toxic to living cells and tissues. Cadmium has been found to be present in the air, food, and even water in alarming amounts. It is a widespread environmental contaminant (Hu, 1998; WHO, 1992). Cadmium has no essential biological function.

Arsenic (As) is a metalloid and a member of group $\mathrm{V}$ of the periodic table of elements. Being a metalloid, it is

\section{Springer Open}

๑ The Author(s). 2020 Open Access This article is licensed under a Creative Commons Attribution 4.0 International License, which permits use, sharing, adaptation, distribution and reproduction in any medium or format, as long as you give appropriate credit to the original author(s) and the source, provide a link to the Creative Commons licence, and indicate if changes were made. The images or other third party material in this article are included in the article's Creative Commons licence, unless indicated otherwise in a credit line to the material. If material is not included in the article's Creative Commons licence and your intended use is not permitted by statutory regulation or exceeds the permitted use, you will need to obtain permission directly from the copyright holder. To view a copy of this licence, visit http://creativecommons.org/licenses/by/4.0/. 
capable of forming alloys with metals and it also readily forms covalent bonds with carbon, hydrogen, and oxygen. Arsenic exists in several different oxidation states, and its chemistry is rather complex. Arsenic compounds are used as preservatives of animal hides, in pigments and dyes, agricultural pesticides, glass manufacture, and various pharmaceutical substances (ATSDR, 2000).

Several studies have shown high levels of these metals in water bodies (Chintaka et al., 2016; Mohankumar, Hariharan, \& Rao, 2016), and fish being a major source of protein in the diet of humans and other lower animals have been shown to be a good bioaccumulator of these metals (Bradley \& Morris, 1986; Dimari \& Hati, 2009; Ololade \& Ajayi, 2009; Ololade, Lajide, \& Amoo, 2007; Roesijadi, 1996). This have raised great concerns on the safety of food and food supplies on human health (Bajpai \& Upreti, 2012; Iwegbue, 2011).

Previous studies of the effect of cadmium and arsenic on animal models focus primarily on only one metal in high concentration and direct exposure. However, environmentally, humans are exposed to a mixture of toxic elements mostly through the food chain and water. Studies are therefore needed to assess the combination of these elements through the food chain. These models have been applied to numerous mixtures (Lu et al., 2014; Spurgeon et al., 2010; Yuan et al., 2014). However, limited data is available on the toxic effects of cadmium and arsenic through the food chain. In addition, available experimental evidence indicates that the absorption and toxicity of both elements are influenced by their mode of metabolism (Masami \& Manabu, 2000; Obinaju, 2009). Thus, the difference in the mode of metabolism of cadmium and arsenic through the controlled food chain makes the need for a study on the comparative absorption and toxicity of both elements imperative. The present study thus investigates the effect of cadmium and arsenic in single and mixture through the food chain on mRNA expression of the liver and kidney of experimental rats.

\section{Materials and methods}

\section{Exposure of fish to metals and diet preparation}

Fish obtained from a local fish pond in Orogun, Delta State, were divided into groups and left to acclimatize for 1 week in plastic troughs. The fish were divided into group A which served as the control. Fish in groups B, C, and D were exposed to cadmium, arsenic, and cadmium + arsenic at a concentration of $0.4 \mathrm{mg}$ metal $/ 100 \mathrm{ml}$ of water for 1 month. The concentration of $0.4 \mathrm{mg} / 100 \mathrm{ml}$ of water was done to achieve the highest accumulation of these metals in the tissues of the fish at a sublethal dose based on previous studies (Ahmad, Qureshi, Manohar, Kaur, \& Khaliq, 2011; Aruljothi \& Samipillai, 2014; Chaudhari, Harshad, \& Kakade and Thorat S. R., 2015; Kumar \&
Banerjee, 2012). The water was changed daily, and so contamination was repeated on a daily basis also. On the completion of 1-month exposure, the fish were sacrificed, strictly maintaining their groups; dried in an oven; and used as a source of protein in compounding the experimental diet. The experimental diet was made up of $20 \%$ protein (contaminated fish), 55\% carbohydrate, 10\% fats, $10 \%$ fiber, and $10 \%$ multivitamin/mineral mix.

\section{Treatment of animals}

Sixty-four adult male albino rats of Wistar strain were obtained from the animal house of the Faculty of Science and used for the study. The rats were divided into groups A, B, C, and D which represents the control, cadmium-contaminated, arsenic-contaminated, and cadmium + arsenic-contaminated groups, respectively. Rats were allowed free access to the experimental diet and water for a period of 1 and 3 months. After the 1-month exposure, half the number of rats in each group were sacrificed and the other half sacrificed after the 3-month exposure under chloroform anesthesia. Animal treatment is in accordance with the Nation Institute of Health guidelines (1985).

\section{Metal analysis}

The feed and tissue samples were digested with $20 \mathrm{ml}$ of concentrated acid mixture $\left(98 \% \mathrm{w} / \mathrm{v} \mathrm{HNO}_{3} / \mathrm{HClO}_{4} ; 4: 1\right.$ $\mathrm{v} / \mathrm{v})$ at $100^{\circ} \mathrm{C}$. After digestion of samples, the $\mathrm{Cd}$ and $\mathrm{As}$ concentrations in the tissues and feeds were measured using a Varian AA 1475 spectrophotometer. An International Atomic Energy Agency (IAEA) reference biological sample was used for the evaluation of the accuracy and precision of the analysis.

\section{Biochemical analysis}

Tissue homogenates were prepared and centrifuged, and supernatant used for biochemical analysis. The activities of superoxide dismutase (SOD), catalase (CAT), and glutathione-s-transferase (GST) were assayed based on the methods of Misra and Fridovich (1972), Sinha (1972), and Habig, Pabst, and Jakoby (1974), respectively. The levels of reduced glutathione (GSH) and lipid peroxidation were determined using the method of Beutler, Duron, and Kelly (1963) and Gutteridge and Wilkins (1982), respectively.

\section{Isolation and purification of RNA from GITC lysate}

The guanidine isothiocyanate (GITC) lysate of tissue samples was prepared. Total RNA of the GITC lysate of liver and kidney were extracted using Reliaprep RNA Kit, a product of Promega Corporation (AppendixII). The integrity and purity of RNA obtained were electrophoretically verified by formaldehyde agarose gel stained with ethidium bromide based on the method of Lehrach, Diamond, Wozney, and Boedtker (1977). 


\section{cDNA synthesis protocol}

In a reverse transcription reaction mixture containing $1 \times$ PCR buffer, $0.5 \mathrm{mMdeoxy}$-nucleoside triphosphates (dNTPs), one unit of RNase inhibitor, $2.5 \mu \mathrm{M}$ of oligo $\mathrm{d}(\mathrm{T}) 16$, and 2.5 units of MuLV reverse transcriptase (Perkin-Elmer, Roche Molecular Systems, Inc, NJ, USA), $1 \mu \mathrm{g}$ of RNA was reverse transcribed into cDNA. After $10 \mathrm{~min}$ of incubation at room temperature to allow primer annealing, the reaction mixture was incubated at $42{ }^{\circ} \mathrm{C}$ for $15 \mathrm{~min}$, heated to $95^{\circ} \mathrm{C}$ for $5 \mathrm{~min}$, and chilled at $4^{\circ} \mathrm{C}$ for $5 \mathrm{~min}$ in a GeneAmp thermal cycler (Applied Biosystems). Two microliters of the resultant cDNA products was used for PCR amplification.

\section{Real-time quantitative reverse transcription polymerase chain reaction}

Real-time quantitative reverse transcription polymerase chain reaction (qRT-PCR) was performed on a Lightcycler 2.0 system (Roche Applied Systems) to analyze the expression levels of mRNA of $\mathrm{Bax}$ and $\mathrm{Bcl}-2$ gene relative to glyceraldehyde-3-phosphate dehydrogenase (GAPDH). Primer sets for GAPDH, Bax, and Bcl-2 were designed using the real-time quantitative PCR probe design software (Roche Applied Systems). The primers used for the amplification of the respective genes are listed in Table 1. PCR reactions for these primers were first optimized using conventional PCR.

For the quantitative real-time PCR, $20 \mu \mathrm{l}$ amplification mixtures (LightCyclerFaststart DNA MasterPLUS SYBR Green Reaction Mix; Roche Applied Science) were prepared per the manufacturer's instructions, containing cDNA (equivalent to $100 \mathrm{ng}$ reverse transcribed RNA) and $0.5 \mu \mathrm{M}$ of each primer. The cycling conditions were as follows: $10 \mathrm{~min}$ polymerase activation at $95^{\circ} \mathrm{C}$ and 40 cycles at $95^{\circ} \mathrm{C}$ for $15 \mathrm{~s}, 58^{\circ} \mathrm{C}$ for $15 \mathrm{~s}$, and $72{ }^{\circ} \mathrm{C}$ for $15 \mathrm{~s}$.

\section{Histological analysis of tissues}

Tissues were stained with hematoxylin and eosin according to McManus and Mowry (1965) and viewed under the microscope. Only the right testis and kidney of each rat were used for the histological examination.

Table 1 Primers used for the amplification of the respective genes in the real-time quantitative reverse transcription polymerase chain reaction ( $\mathrm{R}$ RT-PCR)

\begin{tabular}{ll}
\hline Gene & Primer \\
\hline GAPDH & F: GGCTCTCTGCTCCTCCCTGTTCTA \\
& R: TGCCGTTGAACTTGCCGTGG \\
BCl2 & F: CTG GTG GAC AAC ATC GCT CTG \\
& R: GGT CTG CTG ACC TCA CTT GTG \\
Bax & F: TTCATC CAGGAT CGA GCA GA \\
& R: GCA AAG TAG AAG GCA ACG \\
\hline
\end{tabular}

\section{Statistical analysis}

All the data are expressed as mean \pm standard deviation (SD). Statistical comparisons were performed by one-way analysis of variance (ANOVA) followed by Fisher's least significant difference (LSD). The SPSS software (version 20) was used in the statistical analysis using multiple comparison tests. A $P$ value of less than $0.05(P<0.05)$ was considered significant.

\section{Results}

The results of metal analyses carried out on the feed and rats' tissues for various groups are shown in Tables 2 and 3 , respectively. Table 2 shows the trace amount of arsenic in the control group while the level of cadmium was below detection limit. Results shown in Table 3 indicate that after the 1-month exposure, there was greater accumulation of both metals in the liver than in the kidney, but at the end of the 3-month exposure, the trend changed with the kidney recording the highest accumulation of these metals.

The effects of the treatment on the antioxidant status of the liver and kidney are shown in Tables 4, 5, and 6 . After both period of exposure, the activities of SOD, GST, and CAT were significantly $(P<0.05)$ decreased when compared to the control. The activities of AST and ALT in the liver and kidney of experiment rats were increased after both period of exposure. The levels of GSH and MDA were significantly increased when compared to the control for both duration of study.

Figures 1 and 2 show the representative photomicrographs of control and test group tissues of rats exposed to the experimental feed. Light microscopy showed that control tissues appeared normal after both duration of study, but the test groups for the liver show hepatocytes with mild visible dilation, neutrophilic infiltration into sinusoidal space, enlarged hepatocytes, and blurred nuclei. In a similar vein, the kidney shows the loss of histological details and various degenerative changes. The effect of the experimental diet on the mRNA expressions of Bax and $\mathrm{Bcl} 2$ in the liver and kidney of rats is as shown in Figs. 3 and 4 .

Results show that after the 1-month exposure, significant increase $(P<0.05)$ in the level of mRNA expression of the Bax gene was observed for all groups except for the liver in the cadmium-contaminated group. mRNA expression of the $\mathrm{Bcl} 2$ gene also recorded significant decrease $(P<0.05)$ in all group except for the kidney in the arsenic-contaminated diets after the 1-month exposure. After the 3-month exposure, however, mRNA expression of the Bax gene show significant increase $(P<0.05)$ in all groups while the mRNA expression of the $\mathrm{Bcl} 2$ gene was significantly decreased $(P<0.05)$ in all groups. 
Table 2 Concentration of metals in feed given to experimental animals

\begin{tabular}{|c|c|c|c|c|c|}
\hline \multirow[t]{2}{*}{ Groups } & \multicolumn{2}{|c|}{ Metal concentration $(\mathrm{mg} / \mathrm{g})$} & \multicolumn{2}{|c|}{ Metal concentration $\left(\mathrm{mol} / \mathrm{g} \times 10^{-7}\right)$} & \multirow{2}{*}{$\begin{array}{l}\text { Mole ratio (cadmium } \\
\text { to arsenic) } \times 10^{-7}\end{array}$} \\
\hline & Cadmium & Arsenic & Cadmium & Arsenic & \\
\hline Control & Not detected & $0.02 \pm 0.56^{\mathrm{a}}$ & Not detected & 2.67 & - \\
\hline Cd-contaminated diet & $3.68 \pm 0.62^{b}$ & $0.03 \pm 0.07^{\mathrm{a}}$ & 327 & 4.00 & $81.75: 1$ \\
\hline As-contaminated diet & $0.01 \pm 0.32^{\mathrm{a}}$ & $1.82 \pm 0.18^{b}$ & 0.89 & 243 & 1:273.03 \\
\hline $\mathrm{Cd}+$ As-contaminated diet & $3.50 \pm 0.14^{b}$ & $1.52 \pm 0.26^{\mathrm{b}}$ & 311 & 202 & $1.5: 1$ \\
\hline
\end{tabular}

Results are expressed as mean \pm SD. Values not sharing the same superscript in the same column differ significantly at $P<0.05$

\section{Discussion}

The past few decades had witnessed an increased awareness of problems concerning food pollution of which the heavy metals are one of the most accumulative and persistent pollutants. Thus, the possible effects on the general population of long-term low-level exposure to toxic metals have been of concern in recent times. The current study was therefore designed to investigate the toxicological effects of cadmium and arsenic (singly and in combination) on the liver and kidney of rats.

Metal analysis on the compounded experimental feed and tissues of experimental rats as shown in Tables 2 and 3 shows trace contamination of the control and the test group. This is in accordance with the work of Horiguchi, Sato, Konno, and Fukushima (1996). The presence of Cd and As in the liver and kidney of the control rats and test groups which are supposed to be free of either of the metal is an indication that the water and/or feed used was tainted with $\mathrm{Cd}$ and As. This could be attributed to the pervasiveness of $\mathrm{Cd}$ and $\mathrm{As}$ in the general environment today. Results presented in Table 3 show that $\mathrm{Cd}$ and As accumulated more in the liver than kidney after 1 month of exposure. However, after the 3-month exposure, these metals

Table 3 Effect of food chain-mediated exposure to $\mathrm{Cd}$ and As on metal accumulation in the organs of rats

\begin{tabular}{lll}
\hline Group & \multicolumn{2}{l}{ Metal concentration (mg/g tissue) } \\
\cline { 2 - 3 } & Liver & Kidney \\
\hline 1-month exposure & & \\
Control & $0.02 \pm 0.01^{\mathrm{a}}$ & $0.02 \pm 0.09^{\mathrm{a}}$ \\
Cd-contaminated diet & $4.12 \pm 0.34^{\mathrm{b}}$ & $3.01 \pm 1.01^{\mathrm{b}}$ \\
As-contaminated diet & $1.53 \pm 0.03^{\mathrm{c}}$ & $0.38 \pm 0.01^{\mathrm{c}}$ \\
Cd in Cd + As-contaminated diet & $3.83 \pm 0.05^{\mathrm{d}}$ & $2.21 \pm 0.14^{\mathrm{d}}$ \\
As in Cd + As-contaminated diet & $1.38 \pm 0.02^{\mathrm{c}}$ & $0.16 \pm 0.01^{\mathrm{c}}$ \\
3-month exposure & & \\
Control & $0.05 \pm 0.03^{\mathrm{a}}$ & $0.04 \pm 0.02^{\mathrm{a}}$ \\
Cd-contaminated diet & $7.10 \pm 0.92^{\mathrm{b}}$ & $9.54 \pm 0.13^{\mathrm{b}}$ \\
As-contaminated diet & $2.45 \pm 0.21^{\mathrm{c}}$ & $3.21 \pm 1.27^{\mathrm{c}}$ \\
Cd in Cd + As-contaminated diet & $6.24 \pm 0.07^{\mathrm{d}}$ & $7.15 \pm 1.03^{\mathrm{d}}$ \\
As in Cd + As-contaminated diet & $2.01 \pm 0.12^{c}$ & $2.79 \pm 0.01^{c}$ \\
\hline
\end{tabular}

Results are expressed as mean \pm SD. Values not sharing the same superscript in the same column differ significantly at $P<0.05$ were found to accumulate more in the kidney than in the liver. Experimental evidence shows that when metals are administered orally and subcutaneously, more was deposited in the liver than in the kidneys (Asagba, 2010; Pari \& Murugavel, 2005). However, as the duration of exposure increases, there is a gradual mobilization of these metals from the liver to the kidney (Ercal, Gurer-Orhan, \& Aykin-Burns, 2001; Smith, Klei, \& Barchowsky, 2001). This may not be unconnected with the fact that the kidney being an organ whose primary function is the excretion of toxic metabolites is the final destination of these metals from various tissues and plasma. The higher uptake of $\mathrm{Cd}$ and As in the kidney as compared to other organs is in agreement with available reports in literature (Baykov et al., 2003; Crowe \& Morgan, 1997Elsenhans, Strugala, \& SchmannK, 1999; Eriyamremu, Ojimogho, Asagba, \& Lolodi, 2008; Horiguchi et al., 1996; World Health Organization (WHO), 1992).

In the present study, after the 1-month exposure, the activities of the antioxidant enzymes (SOD and CAT) and GST, a phase 1 drug metabolizing enzyme, were elevated in groups $\mathrm{B}, \mathrm{C}$, and $\mathrm{D}$ when compared to group $\mathrm{A}$ in the kidney. The liver, however, recorded significant $(P<0.05)$ decrease in the activities of these enzymes after the 1-month exposure. The decrease in the activities of the enzymes in the liver even at the 1-month exposure could be attributed to the fact that the liver, being the major site of detoxification, gets a higher load of exposure to these metals due to normal metabolic activities. A decreased activity of SOD and CAT as observed after the 3-month exposure in the tissues (as well as 1-month exposure in the liver) reflects elevated production of superoxide radical anions (Yamanaka, Hasegawa, Sawamura, \& Okada, 1991) and insufficient requirement of $\mathrm{NADPH}$, which is required for the activation of CAT from its inactivated form (Kirkman \& Gaetani, 1984). It is noteworthy that inhibition of antioxidant enzymes such as SOD by cadmium has also been linked to displacement of essential cofactor such as $\mathrm{Zn}$ or $\mathrm{Cu}$ or binding to thiol groups of the enzyme (Casalino, Calzaretti, Sblano, \& Landriscina, 2002; Timbrell, 2000).

Lipid peroxidation (LPO) is a degenerative mechanism of membrane component mediated through free radical production in the cell (Veena, Josephine, Preetha, \& Varalakshmi, 2007). Increased LPO implies membrane instability which correlates with decreased activity of SOD 
Table 4 Effect of treatment on enzymatic activities in the liver of experimental rats

\begin{tabular}{|c|c|c|c|c|c|}
\hline \multirow[t]{2}{*}{ Group } & \multicolumn{5}{|l|}{ Parameter } \\
\hline & $\begin{array}{l}\mathrm{CAT}\left(\mu \mathrm{mol} \mathrm{H}_{2} \mathrm{O}_{2} / \mathrm{min} / \mathrm{mg}\right. \\
\text { protein) }\end{array}$ & $\begin{array}{l}\text { SOD (units/g } \\
\text { testis) }\end{array}$ & $\begin{array}{l}\text { GST ( } \mu \text { mol CDNB-GSH complex } \\
\text { formed/min/mg protein) }\end{array}$ & AST & $\mathrm{ALT}$ \\
\hline \multicolumn{6}{|l|}{ 1-month exposure } \\
\hline Control & $98.00 \pm 4.04^{a}$ & $48.50 \pm 2.29^{a}$ & $10.88 \pm 1.69^{a}$ & $39.05 \pm 3.57^{\mathrm{a}}$ & $30.45 \pm 1.23$ \\
\hline Cd-contaminated diet & $89.00 \pm 2.82^{b}(-9.18 \%)$ & $\begin{array}{l}28.28 \pm 0.24^{b} \\
(-41.69 \%)\end{array}$ & $\begin{array}{l}6.36 \pm 0.10^{b} \\
(-41.54 \%)\end{array}$ & $\begin{array}{l}53.31 \pm 3.510^{\mathrm{b}} \\
(36.52 \%)\end{array}$ & $\begin{array}{l}39.56 \pm 3.15 \\
(29.92 \%)\end{array}$ \\
\hline As-contaminated diet & $44.70 \pm 7.07^{\complement}(-54.39 \%)$ & $\begin{array}{l}22.58 \pm 0.21^{\mathrm{b}} \\
(-53.44 \%)\end{array}$ & $\begin{array}{l}3.80 \pm 0.26^{c} \\
(-65.07 \%)\end{array}$ & $\begin{array}{l}67.89 \pm 3.134^{c} \\
(73.85 \%)\end{array}$ & $\begin{array}{l}57.57 \pm 3.12 \\
(89.06 \%)\end{array}$ \\
\hline $\begin{array}{l}\mathrm{Cd}+\text { As-contaminated } \\
\text { diet }\end{array}$ & $76.30 \pm 7.63^{d}(-22.14 \%)$ & $\begin{array}{l}25.75 \pm 0.13^{b} \\
(-46.91 \%)\end{array}$ & $\begin{array}{l}5.17 \pm 0.46^{b} \\
(-52.48 \%)\end{array}$ & $\begin{array}{l}59.48 \pm 4.54^{\mathrm{b}} \\
(52.32 \%)\end{array}$ & $\begin{array}{l}49.76 \pm 0.27 \\
(63.42 \%)\end{array}$ \\
\hline \multicolumn{6}{|l|}{ 3-month exposure } \\
\hline Control & $205.30 \pm 4.10^{a}$ & $46.75 \pm 1.77^{\mathrm{a}}$ & $10.12 \pm 0.04^{a}$ & $37.00 \pm 12.12^{a}$ & $33.25 \pm 1.25^{\mathrm{a}}$ \\
\hline Cd-contaminated diet & $189.85 \pm 2.61^{\mathrm{b}}(-7.53 \%)$ & $\begin{array}{l}22.82 \pm 0.02^{b} \\
(-51.19 \%)\end{array}$ & $\begin{array}{l}6.12 \pm 0.03^{b} \\
(-39.53 \%)\end{array}$ & $\begin{array}{l}29.75 \pm 6.80^{b} \\
(-19.59 \%)\end{array}$ & $\begin{array}{l}21.00 \pm 1.04^{\mathrm{b}} \\
(-36.84 \%)\end{array}$ \\
\hline As-contaminated diet & $136.95 \pm 2.89^{c}(-33.29 \%)$ & $\begin{array}{l}11.91 \pm 0.46^{c} \\
(-74.52 \%)\end{array}$ & $\begin{array}{l}2.22 \pm 0.88^{c} \\
(-78.06 \%)\end{array}$ & $\begin{array}{l}23.75 \pm 7.22^{c} \\
(-35.81 \%)\end{array}$ & $\begin{array}{l}09.25 \pm 3.48^{\mathrm{c}} \\
(-72.18 \%)\end{array}$ \\
\hline $\begin{array}{l}\mathrm{Cd}+\text { As-contaminated } \\
\text { diet }\end{array}$ & $157.35 \pm 3.04^{d}(-23.36 \%)$ & $\begin{array}{l}17.86 \pm 0.93^{c} \\
(-61.80 \%)\end{array}$ & $\begin{array}{l}4.13 .02^{c} \\
(-59.19 \%)\end{array}$ & $\begin{array}{l}27.25 \pm 5.44^{\mathrm{b}} \\
(-26.35 \%)\end{array}$ & $\begin{array}{l}17.75 \pm 2.08^{d} \\
(-46.62 \%)\end{array}$ \\
\hline
\end{tabular}

Results are expressed as mean \pm SD. Values not sharing the same superscript in the same column differ significantly at $P<0.05$. Percentage changes are given relative to control

and CAT as observed in the present study. The apparent increase in lipid peroxidation may be attributed to the accumulation of the heavy metals in the various organs. In the present study, significant $(P<0.005)$ increases in GSH levels in the liver and kidney were observed after the 1 -month exposure; however, at the end of the 3 months of exposure, there was a significant $(P<0.05)$ decrease in the level of
GSH. The increase in tissue GSH content after the 1month exposure might be attributed to GSH rebound through enhancement of ${ }^{\gamma-}$ glutamylcysteine synthase gene expression (Yeh, Cheng, Ou, Whanger, \& Chang, 2002). The depletion of GSH level however recorded after the 3month exposure could be attributed to the oxidation of GSH by free radicals (Manna, Sinha, \& Sil, 2008) or as a

Table 5 Effect of treatment on enzymatic activities in the kidney of experimental rats

\begin{tabular}{|c|c|c|c|c|c|}
\hline \multirow[t]{2}{*}{ Group } & \multicolumn{5}{|l|}{ Parameter } \\
\hline & $\begin{array}{l}\mathrm{CAT}\left(\mu \mathrm{mol} \mathrm{H}_{2} \mathrm{O}_{2} / \mathrm{min} / \mathrm{mg}\right. \\
\text { protein) }\end{array}$ & $\begin{array}{l}\text { SOD (units/g } \\
\text { testis) }\end{array}$ & $\begin{array}{l}\text { GST ( } \mu \mathrm{mol} \text { CDNB-GSH complex } \\
\text { formed } / \mathrm{min} / \mathrm{mg} \text { protein) }\end{array}$ & AST & $\mathrm{ALT}$ \\
\hline \multicolumn{6}{|l|}{ 1-month exposure } \\
\hline Control & $88.70 \pm 5.65^{\mathrm{a}}$ & $39.75 \pm 0.07^{a}$ & $9.01 \pm 1.26^{\mathrm{a}}$ & $27.06 \pm 4.319^{\mathrm{a}}$ & $29.01 \pm 0.93$ \\
\hline Cd-contaminated diet & $112.05 \pm 2.05^{\mathrm{b}}(26.33 \%)$ & $\begin{array}{l}51.00 \pm 2.10^{b} \\
(28.30 \%)\end{array}$ & $\begin{array}{l}17.37 \pm 3.42^{b} \\
(92.79 \%)\end{array}$ & $\begin{array}{l}41.16 \pm 4.26^{b} \\
(52.11 \%)\end{array}$ & $\begin{array}{l}40.67 \pm 1.23 \\
(40.19 \%)\end{array}$ \\
\hline As-contaminated diet & $99.30 \pm 2.56^{c}(11.95 \%)$ & $\begin{array}{l}42.33 \pm 0.18^{c} \\
(6.49 \%)\end{array}$ & $\begin{array}{l}12.37 \pm 0.15^{c} \\
(37.29 \%)\end{array}$ & $\begin{array}{l}30.63 \pm 2.81^{\mathrm{a}} \\
(13.19 \%)\end{array}$ & $\begin{array}{l}36.02 \pm 0.19 \\
(24.16 \%)\end{array}$ \\
\hline $\begin{array}{l}\mathrm{Cd}+\text { As-contaminated } \\
\text { diet }\end{array}$ & $107.55 \pm 2.75^{d}(21.25 \%)$ & $\begin{array}{l}45.50 \pm 0.03^{c} \\
(14.47 \%)\end{array}$ & $\begin{array}{l}15.62 \pm 0.22^{c} \\
(73.36 \%)\end{array}$ & $\begin{array}{l}39.86 \pm 3.24^{b} \\
(47.30 \%)\end{array}$ & $\begin{array}{l}37.12 \pm 0.17 \\
(27.96 \%)\end{array}$ \\
\hline \multicolumn{6}{|l|}{ 3-month exposure } \\
\hline Control & $177.76 \pm 5.36^{\mathrm{a}}$ & $44.67 \pm 0.15^{a}$ & $9.26 \pm 0.25^{a}$ & $32.00 \pm 8.39^{a}$ & $\begin{array}{l}29.50 \pm \\
10.10^{\mathrm{a}}\end{array}$ \\
\hline Cd-contaminated diet & $101.95 \pm 0.21^{\mathrm{b}}(-42.65 \%)$ & $\begin{array}{l}16.77 \pm 0.07^{b} \\
(-62.46 \%)\end{array}$ & $\begin{array}{l}3.53 \pm 0.22^{b} \\
(-61.88 \%)\end{array}$ & $\begin{array}{l}22.75 \pm 15.10^{b} \\
(-28.91 \%)\end{array}$ & $\begin{array}{l}13.51 \pm 4.41^{\mathrm{b}} \\
(-54.20 \%)\end{array}$ \\
\hline As-contaminated diet & $126.70 \pm 4.24^{c}(-28.72 \%)$ & $\begin{array}{l}22.73 \pm 0.59^{c} \\
(-49.12 \%)\end{array}$ & $\begin{array}{l}5.45 \pm 0.26^{c} \\
(-41.14 \%)\end{array}$ & $\begin{array}{l}27.00 \pm 8.39^{b} \\
(-15.63 \%)\end{array}$ & $\begin{array}{l}21.01 \pm 0.30^{c} \\
(-27.08 \%)\end{array}$ \\
\hline $\begin{array}{l}\mathrm{Cd}+\text { As-contaminated } \\
\text { diet }\end{array}$ & $103.05 \pm 2.21^{b}(-42.03 \%)$ & $\begin{array}{l}18.79 \pm 0.05^{b} \\
(-57.94 \%)\end{array}$ & $\begin{array}{l}4.53 \pm 0.53^{b} \\
(-51.08 \%)\end{array}$ & $\begin{array}{l}25.00 \pm 13^{b} \\
(-21.88 \%)\end{array}$ & $\begin{array}{l}19.25 \pm 4.25^{c} \\
(-41.53 \%)\end{array}$ \\
\hline
\end{tabular}

Results are expressed as mean \pm SD. Values not sharing the same superscript in the same column differ significantly at $P<0.05$. Percentage changes are given relative to control 
Table 6 Effect of treatment on MDA and GSH in the liver and kidney of experimental rats

\begin{tabular}{|c|c|c|c|c|}
\hline \multirow[t]{3}{*}{ Group } & \multicolumn{4}{|l|}{ Parameter } \\
\hline & \multicolumn{2}{|l|}{ Liver } & \multicolumn{2}{|l|}{ Kidney } \\
\hline & MDA (units/g tissue) & GSH (mg/g tissue) & MDA (units/g tissue) & GSH (mg/g tissue) \\
\hline \multicolumn{5}{|l|}{ 1-month exposure } \\
\hline Control & $57.46 \pm 3.41^{\mathrm{a}}$ & $22.67 \pm 2.30^{\mathrm{a}}$ & $47.03 \pm 2.46^{\mathrm{a}}$ & $21.33 \pm 6.11^{\mathrm{a}}$ \\
\hline Cd-contaminated diet & $62.25 \pm 3.65^{b}(8.34 \%)$ & $31.33 \pm 1.15^{b}(38.20 \%)$ & $74.13 \pm 2.03^{b}(57.63 \%)$ & $51.00 \pm 16.97^{\mathrm{b}}(139.10 \%)$ \\
\hline As-contaminated diet & $95.21 \pm 2.54^{\complement}(65.70 \%)$ & $42.00 \pm 2.82^{\complement}(85.27 \%)$ & $58.88 \pm 2.52^{c}(25.20 \%)$ & $48.07 \pm 19.07^{c}(125.36 \%)$ \\
\hline $\mathrm{Cd}+$ As-contaminated diet & $75.60 \pm 1.27^{d}(31.57 \%)$ & $34.33 \pm 2.30^{\mathrm{b}}(51.43 \%)$ & $69.31 \pm 2.87^{d}(47.37 \%)$ & $33.09 \pm 1.41^{d}(55.13 \%)$ \\
\hline \multicolumn{5}{|l|}{ 3-month exposure } \\
\hline Control & $94.38 \pm 1.43^{\mathrm{a}}$ & $32.10 \pm 2.92^{\mathrm{a}}$ & $52.04 \pm 2.33^{\mathrm{a}}$ & $46.03 \pm 4.34^{\mathrm{a}}$ \\
\hline Cd-contaminated diet & $115.63 \pm 1.98^{\mathrm{b}}(22.51 \%)$ & $25.03 \pm 2.64^{\mathrm{b}}(-22.02 \%)$ & $110.02 \pm 1.97^{\mathrm{b}}(111.41 \%)$ & $20.42 \pm 2.82^{\mathrm{b}}(-55.64 \%)$ \\
\hline As-contaminated diet & $162.42 \pm 2.75^{\complement}(72.09 \%)$ & $17.00 \pm 5.65^{\complement}(-47.04 \%)$ & $74.15 \pm 0.62^{\complement}(42.49 \%)$ & $35.01 \pm 1.41^{c}(-23.94 \%)$ \\
\hline $\mathrm{Cd}+$ As-contaminated diet & $126.65 \pm 2.15^{d}(34.19 \%)$ & $23.33 \pm 4.04^{\mathrm{b}}(-27.32 \%)$ & $105.34 \pm 2.94^{d}(102.42 \%)$ & $31.30 \pm 2.48^{\complement}(-32.00 \%)$ \\
\hline
\end{tabular}

Results are expressed as mean \pm SD. Values not sharing the same superscript in the same column differ significantly at $P<0.05$. Percentage changes are given relative to control

\section{a}

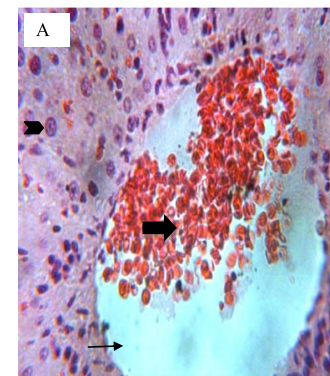

Liver histology with distinct visible centrioles (small arrow) with well fenestrated sinusoidal space. The hepatocytes appear distinc
(Arrow head) with well differentiated nucleus. Some red blood cells seen in the centrioles (big arrow)

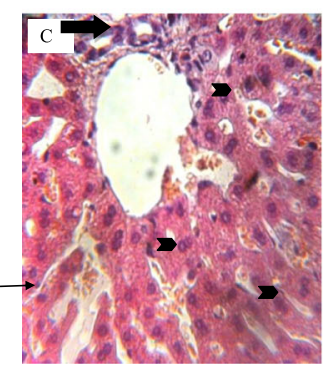

The hepatocytes cytoplasm is light, foamy and vacuolated;(arrow head) cell sizes are
enlarged, nuclear chromatin is more compact, (small arrow) slightly smaller nucleoli are not conspicuous. Visible mononuclear cells in the vicinity of the sinusoids.(big arrow) The sinusoid walls

\section{b}

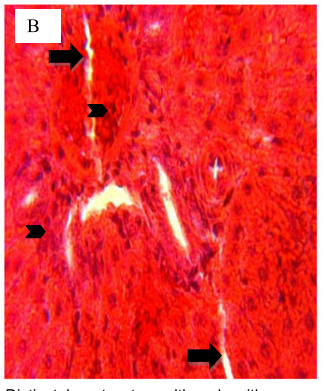

Distinct hepatocytes, although with some mild visible dilation in the sinusoidal space
(big arrow). There is also congestion in the (big arrow). There is also congestion in the sinusoidal space (arrow head)

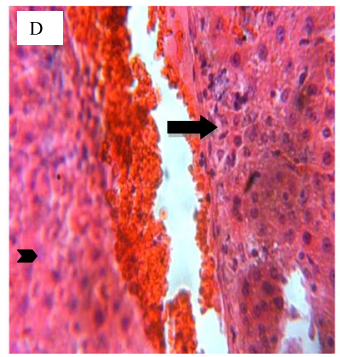

Visible centrioles, the cytoplasm of some hepatocytes are enlarged with some visible hepatocytes, the structure of nuclei is appears blurred (arrow head). b

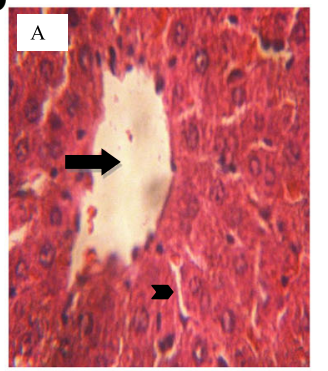

Visible centrioles (Big arrow) with well fenestrated sinusoidal space. The hepatocytes appear distinct with well
differentiated nucleus.( arrow head)

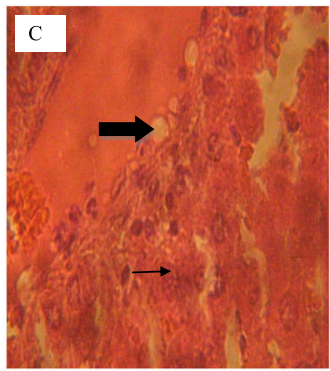

Most hepatic lobules, the trabecular structure is lightly blurred and, in the remaining lobules, distinctly blurred. (small arrow). The cytoplasm of some cells shows rare empty vacuole-type spaces. A relative number of fat cells are observed in the sinusoid wall and mesnification (Big and cow

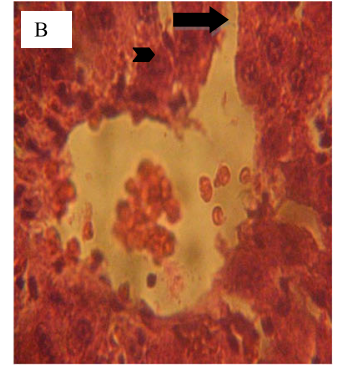

Distinct hepatocytes, although with some mild visible dilation in the sinusoidal space. (Big arrow) There is also mild congestion in the centrioles with noticeable inflites in the sinusoidal space (arrow head)

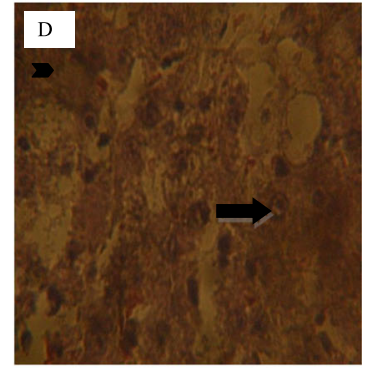

The trabecular structure of the lobules is blurred in some places (small arrow). The cytoplasm of some hepatocytes is enlarged
light, with vacuoles. In most hepatocytes, the structure of nuclei is distorted.(large arrows)

Fig. 1 a Morphological changes in the liver of rats exposed to contaminated diet after 1-month exposure. (A) Control. (B) Cd-contaminated diet. (C) As-contaminated diet. (D) Cd + As-contaminated diet. b Morphological changes in the liver of rats exposed to contaminated diet after 3-month exposure. (A) Control. (B) Cd-contaminated diet. (C) As-contaminated diet. (D) Cd + As-contaminated diet 


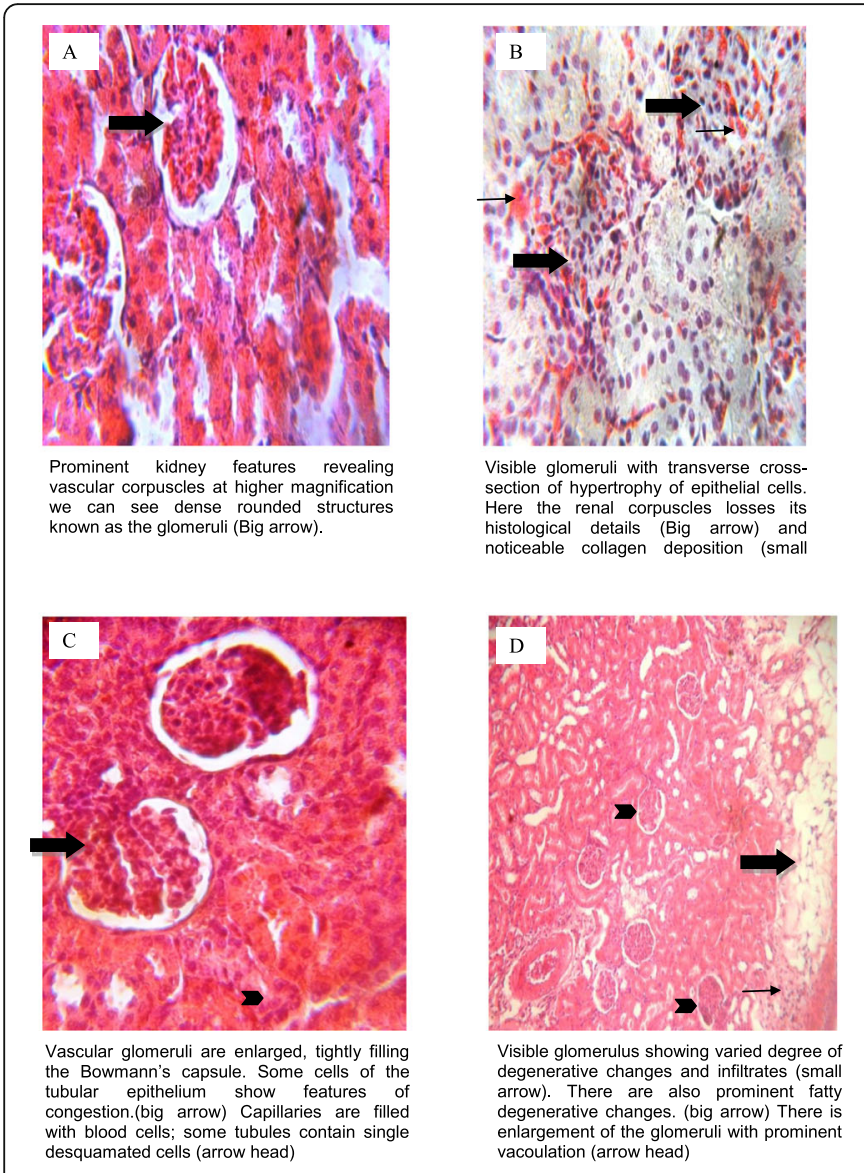

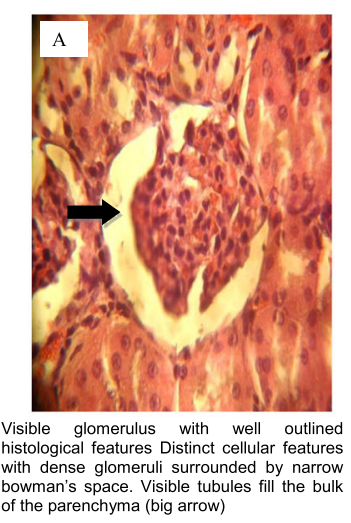

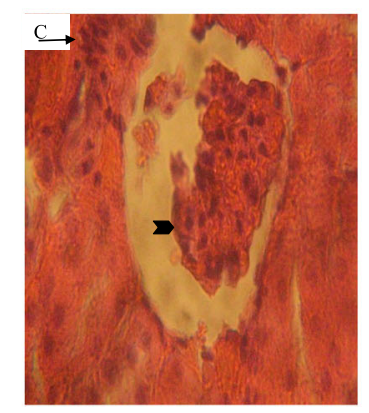

A transverse cross-section of thick Henle's loops shows hypertrophy of epithelial cells, frequently with signs of oedema. (large arrow) Distinct infiltration of mononuclear cells can be seen in places where tubular epithelium arrow)

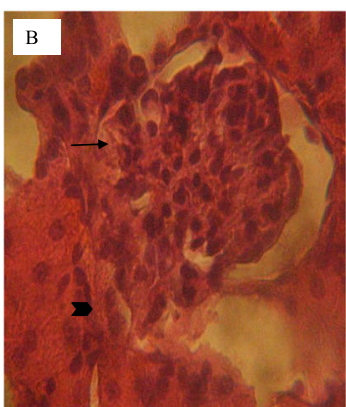

Visible glomerulus showing varied degree of necrotic and degenerative changes. There changes. At high magnification there is elargement of the glomeruli with prominent vacoulation mild cytoplasmic blabbing and moderate necrosis, hydropic and fatty degenerative changes in distal tubules

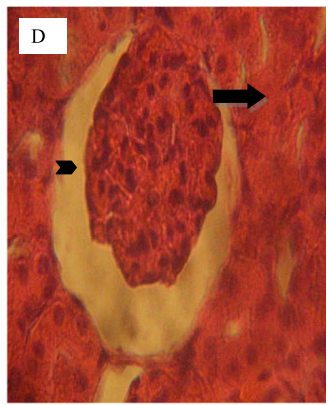

Vascular glomeruli is shrinked, loosely filling the Bowmann's capsule.(arrow head) Some cells of the I-row tubular epithelium show features of oedema. Capillaries are filled with (big arrow)

Fig. 2 a Morphological changes in the kidney of rats exposed to contaminated diet after 1-month exposure. (A) Control. (B) Cd-contaminated diet. (C) As-contaminated diet. (D) Cd + As-contaminated diet. b Morphological changes in the kidney of rats exposed to contaminated diet after 3-month exposure. (A) Control. (B) Cd-contaminated diet. (C) As-contaminated diet. (D) Cd + As-contaminated diet

result of depletion of the sulfhydryl group of cysteine moiety in GSH due to its high affinity for cadmium and arsenic forming Cd/As-GSH complex (Aposhian, Zakharyan, Wildfang, et al., 1999a) or its electron donor ability (Radabaugh \& Aposhian, 2000).

Histopathological analysis shows treatment-related lesions in the various tissues/groups studied. Photomicrographs of the liver for both duration of study showed that arsenic had more deleterious effect on the liver than cadmium or the mixture of metals. After the 1-month exposure, arsenic was able to induce a light, foamy, and vacuolated cytoplasm while at the end of the 3month exposure, the cytoplasm of cells shows rare empty vacuole-type spaces and a number of Kupffer cells are observed in the sinusoid wall. In the kidney, however, cadmium exerted more deleterious effects than the mixture or arsenic alone. In the kidney, after the 1-month treatment, cadmium was able to induce visible dilation in the sinusoidal space, mild congestion in the centrioles, and noticeable infiltrates in the sinusoidal space. Also, the renal corpuscles lost their histological details and there was a noticeable collagen deposition.

After the 3-month exposure, examination of the photomicrograph of the organs indicates that the glomerulus shows varied degree of necrotic and degenerative changes. Elsenhans et al. (1999) had reported that the kidneys are the critical target following long-term exposure to cadmium. Cadmium-induced hepatic and renal injury in chronically exposed rats shows the likely role of hepatic cadmium-metallothionein in nephrotoxicity (Dudley, Gammal, \& Klaassen, 1985). Jadhav et al. (2007, b) investigated the effect of subchronic exposure of rats to drinking water containing arsenic, cadmium, lead, mercury, chromium, nickel, manganese, and iron. The results showed that the 3-month exposure of rats to the mixture of elements led to substantial changes in humoral and cellmediated immune responses, in biochemical parameters, and even in vascular, degenerative, and necrotic changes in tested tissues of rats.

The effect of the experimental diet on the mRNA expressions of $\mathrm{Bax}$ and $\mathrm{Bcl} 2$ was also analyzed in the current 


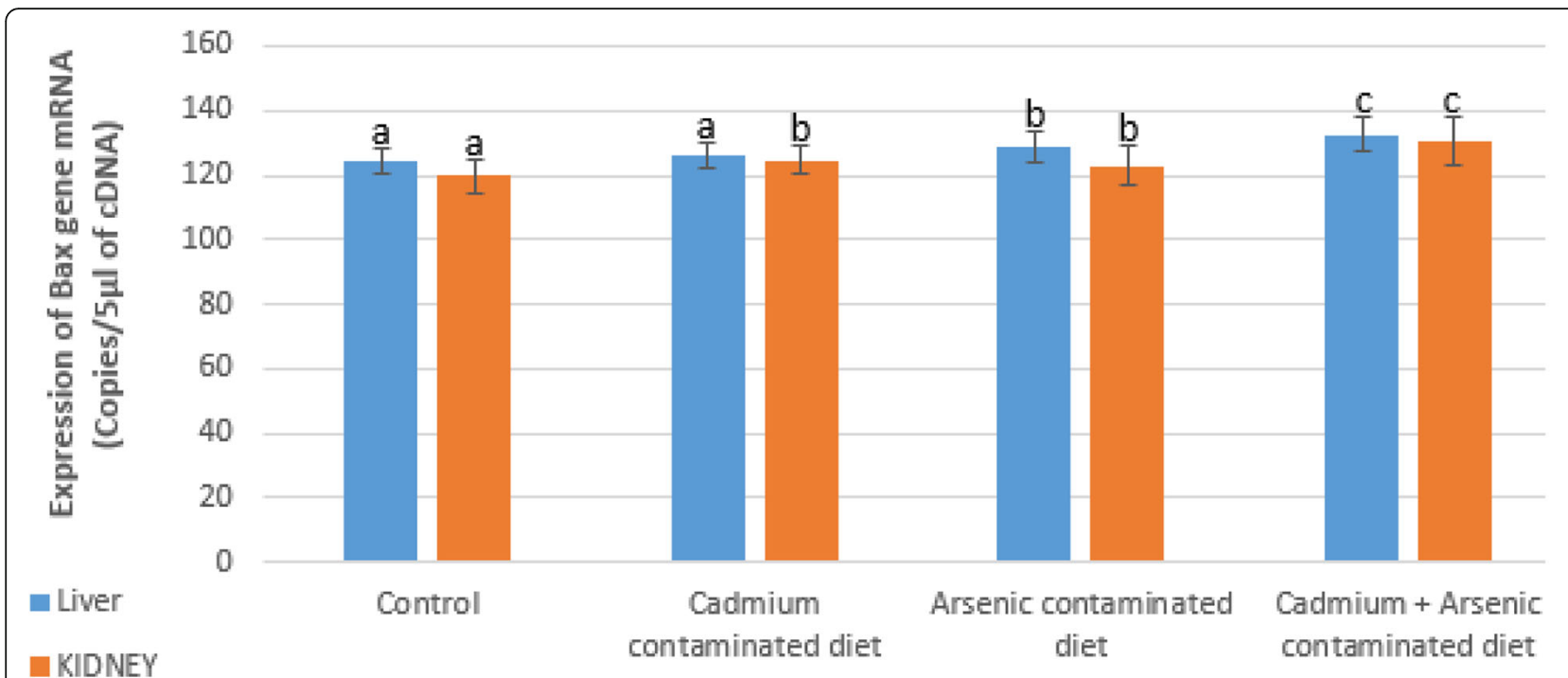

1 Month Exposure

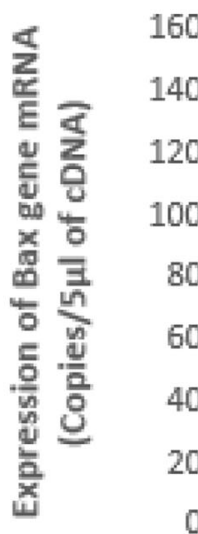

口 LIVER - KIDNEY

160

140

120

100

60

40
80

20

0

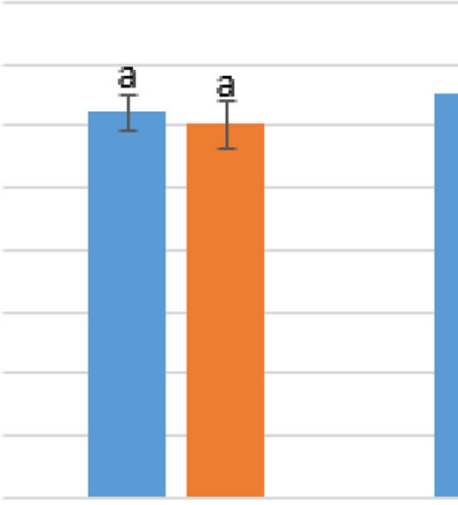

Control
Arsenic contaminated

diet

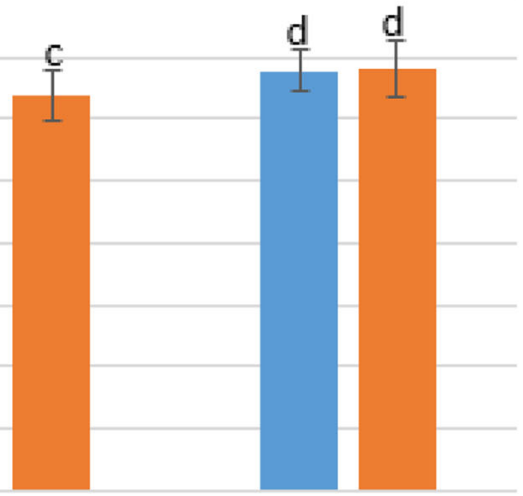

Cadmium + Arsenic contaminated diet

3 Months Exposure

Fig. 3 Changes in the expression of Bax gene mRNA in the liver and kidney of rats after 1- and 3-month exposures to experimental diet. Values not sharing the same superscript within a tissue differ significantly at $P<0.05$

study (Figs. 3 and 4). One month after exposure to these metals through the food chain, there was a significant $(P<0.005)$ increase in the level of Bax mRNA in the kidney and liver of rats except for the liver which was exposed to cadmium-contaminated diet only. The levels of Bcl-2 were, however, non-significantly $(P<0.005)$ downregulated in all groups except for the kidney in the arseniccontaminated diet. After the 3-month exposure, Bcl-2 was significantly $(P<0.05)$ downregulated while Bax was significantly $(P<0.05)$ increased in all test groups in the liver and kidney. Interactions between $\mathrm{Bcl}-2$ and Bax regulate cytochrome c release from mitochondria and establish baseline sensitivity to apoptotic stimuli. El-Sayed, Salem,
El-Garhy, Rahman, and Kandil (2013) reported that cadmium administrated to pregnant mice increased primary DNA damage and activated the apoptotic pathway. Bcl-2 and Bax produce mitochondrial-related proteins with antagonistic effects; the former having an anti-apoptotic activity and the latter a pro-apoptotic activity.

Very little information is available on the interactive effects of As and Cd upon ingestion. Fowler and Mahaffey (1978), Mahaffey and Fowler (1977), Schmolke, Elsenhans, Ehtechami, and Forth (1992), and Mahaffey, Capar, Gladen, and Fowler (1981) have shown using subchronic dietary studies in rats that neither metal significantly affected accumulation of the other in the 


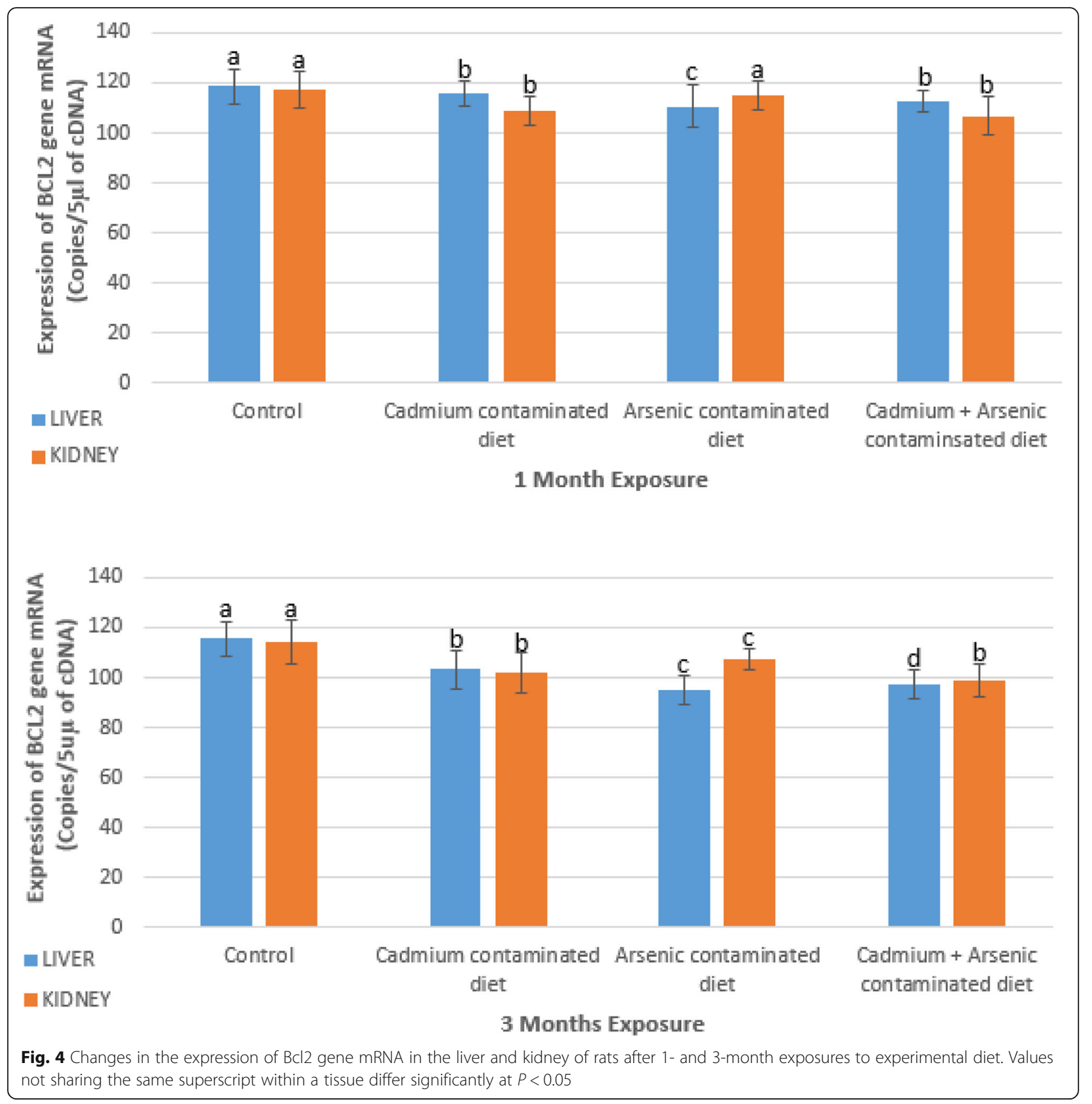

kidney, liver, or brain tissue. Contrary to the observation of Diaz-Barriga et al. (1990) and Yanez, Carrizales, Zanatta, Mejia, and BatRes.L. and Diaz-Barriga F. (1991) that showed that As (as arsenite) and Cd were more lethal to rats when administered as a mixture than when injected alone, the present study showed that arsenic was more toxic to the liver than the mixture while cadmium showed more deleterious effects on the kidneys than the mixture. Thus, both metals appear to be antagonistic to each other when consumed together. This could be attributed to the fact that in the mixture, arsenic together with cadmium was able to induce the synthesis of metallothioneins. Thus, while all of the arsenics absorbed in the intestines of rats in group $\mathrm{C}$ are available to exert their toxic effect, in group $\mathrm{D}$, where the mixture of the metals was included in the experimental diet, some of the arsenic might have been bounded by metallothionein induced in the liver due to the presence of cadmium. Falnoga et al. (2000) have shown that metallothionein is also capable of binding to arsenic, and so reduce the amount of arsenic available for toxicity. Metallothionein has thus been shown to prevent acute cadmium-induced hepatotoxicity and cell death in animal studies (Klaassen, Liu, \& Choudhuri, 1999). Studies (Diaz- 
Barriga et al., 1990; Yanez et al., 1991) have also shown that $\mathrm{Cd}$-induced toxicity could be inhibited by As-induced glutathione. In addition, studies have shown that MMA and DMA are toxic forms of arsenic due to the ability to induce enzyme inhibition, oxidative stress, DNA damage, and complex with glutathione and other sulfhydryl proteins in enzymes (Ercal et al., 2001; Goering, Aposhian, Mass, et al., 1999; NAS, 2001).

The results of the present study are in consonance with the report of Yanez et al. (1991) which showed that the toxicity of a mixture of As $+\mathrm{Cd}$ cannot be predicted from the toxic mechanisms of single components. They also demonstrated differences between the mechanisms of toxic behavior of both elements. In their experiment, the mixture of As $+\mathrm{Cd}$ behaved as arsenic in the induction of lipid peroxidation and glutathione and as cadmium in the metallothionein induction.

\section{Conclusion}

This study has provided evidence that cadmium and arsenic, at low concentrations through a controlled food chain, can potentially be accumulated in fish in their natural habitat which can be passed on to the next trophic level through the food chain as evidenced by the metal burdens recorded in the tissues of experimental rats. The cadmium-contaminated diet was found to be more toxic to the kidney than the liver while the arsenic-contaminated diet was found to be toxic to the liver. These toxicities altered the activities of the examined enzymes as well as the levels of GSH and MDA and expression levels of mRNA of $\mathrm{Bax}$ and $\mathrm{Bcl}$ genes of exposed rats. Treatment-related morphological changes were also observed in the tissues of experimental rats. In addition, the present study has shown that the toxicity of a mixture of As + Cd cannot be predicted from the toxic mechanisms of the single components.

\section{Abbreviations \\ As: Arsenic; CAT: Catalase; Cd: Cadmium; cDNA: Complementary DNA: dNTPs: Deoxnucleoside triphosphates; GAPDH: Glyceraldehyde-3-phosphate dehydrogenase; GITC: Guanidine isothiocyanate; GSH: Reduced glutathione; GST: Glutathione-s-transferase; LPO: Lipid peroxidation; mRNA: Messenger ribonucleic acid; NADPH: Reduced form of nicotinamide adenine dinucleotide phosphate; PCR: Polymerase chain reaction; GRT-PCR: Real-time quantitative reverse transcription polymerase chain reaction; RNA: Ribonucleic acid; SD: Standard deviation; SOD: Superoxide dismutase}

\section{Acknowledgements}

Not applicable

\section{Authors' contributions}

ET contributed to the conception and design of the study, acquisition of materials required for the study, and analysis and interpretation of data; drafted the manuscript; critically revised the manuscript; and agreed to be accountable for all aspects of work ensuring integrity and accuracy. AOS also contributed to the conception and design of the study and acquisition of materials required for the study, gave the final approval, and agreed to be accountable for all aspects of work ensuring integrity and accuracy. TJN also contributed to the conception and design of the study and analysis and interpretation of data. The authors read and approved the final manuscript.

\section{Funding}

The present study was self-funded by the authors

\section{Availability of data and materials}

The datasets analyzed during the current study are available from the corresponding author on reasonable request.

\section{Ethics approval and consent to participate}

The research was carried out in accordance with the National Institute of Health $(\mathrm{NIH})$, and approval was given by the Committee on Animal Research and Ethics, Faculty of Basic Medical Sciences, Delta State University, Abraka, Nigeria.

\section{Consent for publication}

Not applicable

\section{Competing interests}

The authors declare that they have no competing interests.

Received: 25 April 2019 Accepted: 28 February 2020

Published online: 16 April 2020

\section{References}

Agency for Toxic Substances and Disease Registry (ATSDR) (2000). Toxicological profiles for Arsenic. Atlanta: U.S. Department of Health and Human Services, Public Health Service. 140

Ahmad, B., Qureshi, T. A., Manohar, S., Kaur, P., \& Khaliq, R. (2011). Effect of cadmium chloride on the histoarchitecture of liver and kidney of a freshwater catfish, Clarias batrachus. International Journal of Environmental Sciences, 2, 531-539.

Aposhian, H. V., Zakharyan, R. A., Wildfang, E. K., et al. (1999a). How is inorganic arsenic detoxify? In W. R. Chappell, C. O. Abernathy, \& R. L. Calderon (Eds.), Arsenic: exposure and health effects, (pp. 289-297). New York, NY: Elsevier Science Ltd.

Aruljothi, B., \& Samipillai, S. S. (2014). Effect of arsenic on lipid peroxidation and antioxidants system in fresh water fish, Labeo rohita. International Journal of Medical Research \& Review, 2(1), 15-19.

Asagba, S. O. (2010). A comparative study on the biochemical effect of ocular and oral cadmium administration in rabbits. African Journal of Biotechnology, 9(21), 3016-3025.

Bajpai R, Upreti D. (2012). Accumulation and toxic effect of arsenic and other heavy metals in a contaminated area of West Bengal, India, in the lichen Pyxinecocoes (SW. ) Nyl. Ecotoxicology and Environmental Safety.83:63-70

Baykov, B. D., Hristev, H. R., Penkov, D., Zaharinov, B., Georgieva, Y. U., WillekeWetstein, C. H., \& Steinbach, J. (2003). Movement of cadmium and lead in anthropogenically formed trophic chains of a pasture type. Journal of Central European Agriculture, 4(4), 389-398.

Beutler, E., Duron, O., \& Kelly, B. M. (1963). Improved method for determination of blood glutathione. The Journal of Laboratory and Clinical Medicine, 61, 882-888.

Bradley R. W. and Morris J.R. (1986). Heavy metals in fish from a series of metalcontaminate lakes near Sudbury, Ontario. Water, Air, and Soil Pollution. 27: 341-354.

Casalino, E., Calzaretti, G., Sblano, C., \& Landriscina, C. (2002). Molecular inhibitory mechanisms of antioxidant enzymes in rat liver and kidney by cadmium. Toxicology, 179, 37-50.

Chaudhari, R. T., Harshad, R., \& Kakade and Thorat S. R. (2015). Effect of cadmium chloride on the biochemical charecteristics of fresh water fish, Cyprinus carpio. International Journal of Management and Social Science Research Review, 3, 85-89.

Chintaka, P. A., Perera, T., Thenmoli, V., Sundarabarathy, T. V., Sivananthawerl, T., Kodithuwakku, P. S., \& Edirisinghea, U. (2016). Arsenic and cadmium contamination in water, sediments and fish is a consequence of paddy cultivation: Evidence of river pollution in Sri Lanka. Achievements in the Life Sciences, 10(2), 144-160.

Crowe, A., \& Morgan, E. H. (1997). Effect of dietary cadmium on iron metabolism in growing rats. Toxicology and Applied Pharmacology, 145(1), 136-146.

Diaz-Barriga, F., Llamas, E., Mejia, J. J., Carrizales, L., Santoyo, M. E., Vega-Vega, L., et al. (1990). Arsenic-cadmium interaction in rats. Toxicology, 64, 191-203.

Dimari, G. A., \& Hati, S. (2009). Interaction profile for As, Cd, Cr and Pb in tissues of fishes (Tilapia gallier, Clariaslazera and Heterotisniloticus). Scientific Research and Essays, 4(9), 894-899. 
Dudley, R. E., Gammal, L. M., \& Klaassen, C. (1985). Cadmium induced hepatic and renal injury in chronically exposed rats: Likely role of hepatic cadmium metallothionine in nephrotoxicity. Toxicology and Applied Pharmacology, 77, 414.

Eichler, T., Ma, Q., Kelly, C., Mishra, J., Parikh, S., Ransom, R. F., ... Smoyer, W. E. (2006). Single and combination toxic metal exposures induce apoptosis in cultured murine podocytes exclusively via the extrinsic caspase 8 pathway. Toxicological Sciences, 90(2), 392-399.

El-Sayed, A., Salem, M. S., El-Garhy, A. A., Rahman, A. Z., \& Kandil, M. A. (2013). Protective effect of zinc against cadmium toxicity on pregnant rats and their fetuses at morphological, physiological and molecular level. African Journal of Biotechnology, 12(16), 2110-2119.

Elsenhans, B., Strugala, G., \& SchmannK (1999). Longitudinal pattern of enzymatic and absorptive functions in the small intestine of rats after short term exposure to dietary cadmium chloride. Archives of Environmental Contamination and Toxicology, 36, 341-346.

Ercal, N., Gurer-Orhan, H., \& Aykin-Burns, N. (2001). Toxic metals and oxidative stress part 1: Mechanisms involved in metal-induced oxidative damage. Current Topics in Medicinal Chemistry, 1(6), 529-539.

Eriyamremu, G. E., Ojimogho, S. E., Asagba, S. O., \& Lolodi, O. (2008). Changes in brain, liver and kidney lipid peroxidation, antioxidant enzymes and ATPases of rabbits exposed to cadmium ocularly. Journal of Biological Sciences, 8(1), 67-73.

Falnoga, I., Stibilj, V., Tusek-Znidaric, M., Slejkovec, Z., Mazej, D., Jacimovic, R., \& Scancar, J. (2000). Effect of arsenic trioxide on metallothionein and its conversion to different arsenic metabolites in hen liver. Biological Trace Element Research, 78, 241-254.

Fowler, B. A., \& Mahaffey, K. R. (1978). Interactions among lead, cadmium, and arsenic in relation to porphyrin excretion patterns. Environmental Health Perspectives, 25, 87-90.

Goering, P. L., Aposhian, H. V., Mass, M. J., et al. (1999). The enigma of arsenic carcinogenesis: Role of metabolism. Toxicological Sciences, 49, 5-14.

Gutteridge JMC and Wilkins C. (1982). Copper dependent hydroxyl radica damage to ascorbic acid. Formation of a thiobarbituric acid reactive products. Febs Letters. 137:327-340.

Habig, W. H., Pabst, M. J., \& Jakoby, W. B. (1974). (1974). Glutathione S-transferases. The first enzymatic step in mercapturic acid formation. The Journal of Biological Chemistry, 249, 7130-7139.

Horiguchi, H., Sato, M., Konno, N., \& Fukushima, M. (1996). Long-term cadmium exposure induces anemia in rats through hypoinduction of erythropoietin in the kidneys. Archives of Toxicology, 71, 11-19.

$\mathrm{Hu}$, H. (1998). Heavy metal poisoning. In A. S. Fauci, E. Braunwald, K. J. Isselbacher, et al. (Eds.), Harrison's principle of internal medicine, (14th ed., pp. 2565-2566). McGraw Hill Book Company.

Iwegbue, C. M. A. (2011). Trace metal contents in some brands of canned beef in Nigeria. Toxicological \& Environmental Chemistry., 93, 1368-1374.

Jadhav, S. H., Sarkar, S. N., Patil, R. D., \& Tripathi, H. C. (2007). Effects of subchronic exposure via drinking water to a mixture of eight water-contaminating metals: A biochemical and histopathological study in male rats. Archives of Environmental Contamination and Toxicology, 53, 667-677.

Jadhav, S. H., Sarkar, S. N., Ram, G. C., \& Tripathi, H. C. (2007). Immunosuppressive effect of subchronic exposure to a mixture of eight heavy metals, found as groundwater contaminants in different areas of India, through drinking water in male rats. Archives of Environmental Contamination and Toxicology, 53, 450-458.

Kim, S. C., Cho, M. K., \& Kim, S. G. (2003). Cadmium-induced nonapoptotic cell death mediated by oxidative stress under the condition of sulfhydryl deficiency. Toxicology Letters, 144, 325-336.

Kirkman, H. N., \& Gaetani, G. F. (1984). Catalase: A tetrameric enzyme with four tightly bound molecules of NADPH. Proceedings of the National Academy of Sciences. U S A, 81, 4343-4347.

Klaassen, C. D., Liu, J., \& Choudhuri, S. (1999). Metallothionein: An intracellular protein to protect against cadmium toxicity. Annual Review of Pharmacology and Toxicology, 39, 267-294

Kumar, R., \& Banerjee, T. K. (2012). Analysis of arsenic bioaccumulation in different organs of the nutritionally important catfish, Clarias batrachus (L.) exposed to the trivalent arsenic salt, sodium arsenite. Bulletin of Environmental Contamination and Toxicology, 89(3), 445-449.

Lehrach, H., Diamond, D., Wozney, J. M., \& Boedtker, H. (1977). RNA molecular weight determinations by gel electrophoresis under denaturing conditions, a critical re-examination. Biochemistry., 16, 4743-4751.

Lu, H., Yuan, G., Yin, Z., Dai, S., Jia, R., Xu, J., ... LV, C. (2014). Effects of subchronic exposure to lead acetate and cadmium chloride on rat's bone: $\mathrm{Ca}$ and $\mathrm{Pi}$ contents, bone density, and histopathological evaluation. International Journal of Clinical and Experimental Pathology, 7, 640-647.

Madden, E. F., \& Fowler, B. A. (2000). Mechanisms of nephrotoxicity from metal combinations: A review. Drug and Chemical Toxicology, 23, 1-12.

Mahaffey, K. R., Capar, S. G., Gladen, B. C., \& Fowler, B. A. (1981). Concurrent exposure to lead, cadmium, and arsenic. Effects on toxicity and tissue metal concentrations in the rat. The Journal of Laboratory and Clinical Medicine, 98, 463-481.

Mahaffey, K. R., \& Fowler, B. A. (1977). Effects of concurrent administration of lead, cadmium, and arsenic in the rat. Environmental Health Perspectives, 19, 165-171.

Manna, P., Sinha, M., \& Sil, P. C. (2008). Arsenic-induced oxidative myocardial injury: Protective role of arjunolic acid. Archives of Toxicology, 82, 137-149.

Masami, I., \& Manabu, K. (2000). Regulation of cell fate by cadmium and zinc. Journal of Health Science, 47(1), 9-13.

McManus, F. A., \& Mowry, R. W. (1965). Staining methods. Histology and histochemistry. In Hoeber PB, editor, (pp. 73-90). New York: Harper and Brothers.

Misra, H. P., \& Fridovich, I. (1972). (1972). The role of superoxide ion in autooxidation of epinephrine and a simple assay for superoxide dismutase. The Journal of Biological Chemistry, 247, 3170-3175.

Mohankumar, K., Hariharan, V., \& Rao, N. P. (2016). Heavy metal contamination in groundwater around industrial estate vs residential areas in Coimbatore, India. Journal of Clinical and Diagnostic Research, 10(4), BC05-BC07.

National Academy of Sciences (NAS) (2001). Arsenic in drinking water, (vol. 81). Washington DC: National Academies Press.

National Institutes of Health (NIH) Publication (1985), Guide for the care and use of laboratory animals. No. 85-23.

Obinaju, B. E. (2009). Mechanisms of arsenic toxicity and carcinogenesis. African Journal of Biochemistry Research, 3(5), 232-237.

Ololade, I. A., \& Ajayi, A. O. (2009). Contamination profile of major rivers along the highways in Ondo State, Nigeria. Toxicology and Environmental Health Sciences, 1(3), 038-053.

Ololade, I. A., Lajide, L., \& Amoo, I. A. (2007). Enrichment of heavy metals in sediments as pollution indicator of the aquatic ecosystem. Pakistan Journal of Scientific and Industrial Research, 50(1), 27-35.

Pari, L., \& Murugavel, P. (2005). Role of diallyltetrasulfide in ameliorating the cadmium induced biochemical changes in rats. Environmental Toxicology and Pharmacology, 20, 493-500.

Radabaugh, T. R., \& Aposhian, H. V. (2000). Enzymatic reduction of arsenic compounds in mammalian systems: Reduction of arsenate to arsenite by human liver arsenate reductase. Chemical Research in Toxicology, 13, 26-30.

Roesijadi, G. (1996). Metalothioneins and its role in toxic metal regulation. Comparative Biochemistry and Physiology, 113C, 117-123.

Schmolke, G., Elsenhans, B., Ehtechami, C., \& Forth, W. (1992). Arsenic-copper interaction in the kidney of the rat. Human \& Experimental Toxicology, 11, 315-321.

Sinha, A. K. (1972). Colorimetric assay of catalase. Analytical Biochemistry, 47, 389-394.

Smith, K. R., Klei, L. R., \& Barchowsky, A. (2001). Arsenite stimulates plasma membrane NADPH oxidase in vascular endothelial cells. American Journal of Physiology-Lung Cellular and Molecular Physiology, 280, L442-L449.

Spurgeon, D. J., Jones, O. A., Dorne, J. L., Svendsen, C., Swain, S., \& Sturzenbaum, S. R. (2010). Systems toxicology approaches for understanding the joint effects of environmental chemical mixtures. Science of the Total Environment, 408, 3725-3734.

Timbrell, J. (2000). Principles of biochemical toxicology, (3rd ed., ). London: Taylor and Francis.

Veena, C. K., Josephine, A., Preetha, S. P., \& Varalakshmi, P. (2007). Effect of sulphated polysaccharides on erythrocyte changes due to oxidative and nitrosative stress in experimental hyperoxaluria. Human \& Experimental Toxicology, 26, 923-932.

World Health Organization (WHO) (1992). Environmental Health Criteria 134: Cadmium. Geneva, 280.

Yamanaka, K., Hasegawa, A., Sawamura, R., \& Okada, S. (1991). Cellular response to oxidative damage in lung induced by the administration of dimethylarsinic acid, a major metabolite of inorganic arsenics, in mice. Toxicology and Applied Pharmacology, 108, 205-213.

Yanez, L., Carrizales, L., Zanatta, M. T., Mejia, J. J., \& BatRes.L. and Diaz-Barriga F. (1991). Arsenic-cadmium interaction in rats: Toxic effects in the heart and tissue metal shifts. Toxicology, 67, 227-234.

Yeh, J. Y., Cheng, L. C., Ou, B. R., Whanger, D. P., \& Chang, L. W. (2002). Differential influences of various arsenic compounds on glutathione redox status and antioxidative enzymes in porcine endothelial cells. Cellular and Molecular Life Sciences, 59, 1972-1982. 
Yuan, G., Dai, S., Yin, Z., Lu, H., Jia, R., Xu, J., ... Zhang, M. (2014). Subchronic lead and cadmium co-induce apoptosis protein expression in liver and kidney of rats. International Journal of Clinical and Experimental Pathology, 7(6), 2905-2914.

\section{Publisher's Note}

Springer Nature remains neutral with regard to jurisdictional claims in published maps and institutional affiliations.

Submit your manuscript to a SpringerOpen ${ }^{\circ}$ journal and benefit from:

- Convenient online submission

- Rigorous peer review

- Open access: articles freely available online

- High visibility within the field

- Retaining the copyright to your article

Submit your next manuscript at $\boldsymbol{\wedge}$ springeropen.com 